a working basis and that further investigations into the exact mechanism of elephantiasis should be carried out. Under treatment, Dr. W. H. Wright stressed the inadequacy of information of the lethal action of 'Hetrazan' on the adult worms. The role of anti-histamine drugs and antibiotics, such as penicillin, was discussed. The control and prophylaxis of bancroftian filariasis in the South Pacific was in the hands of Dr. H. K. Beye, field director of the Pacific Tropical Diseases Foundation, University of California, who cited instances where mosquito control had resulted in decrease in the microfilaria rates. Present observations relating to mass drug therapy and mosquito infection rates indicated that the most effective procedure is to keep the blood permanently free of microfilariæ. Dosage schedules of 'Hetrazan' now under investigation give promise of meeting this object. The value of educational and other measures was discussed. Especial importance was paid to the training of native personnel in filariasis control. The subjects of standardization and procedures regarding blood examination and documentation had universal support. Standard methods of recording mosquitoes or their larvæ, the laboratory diagnosis for microfilariæ, the recording of clinical manifestations and standards for intradermal tests were agreed upon.

An annotated bibliography of filariasis is being drawn up especially as regards the South Pacific. Finally, it was decided to publish the final report of the conference as a public document.

As the original work on filariasis in the Pacific was undertaken by a member of the staff of the London School of Tropical Medicine in 1910, and as his results were reinforced and expanded later by O'Connor, Prof. P. A. Buxton and others, it is a considerable source of satisfaction to record that, not only has their work been confirmed, but also that it is now being placed upon a practical basis, so that this, the chief scourge of the Pacific, may soon be eliminated altogether. PhILIP Manson-Bark

\section{THE ANCIENT KHMER EMPIRE}

$\mathrm{A}^{\mathrm{N}}$ $\mathrm{N}$ entertaining and scholarly history of the Khmer Empire from the first to the fifteenth centuries, entitled "The Ancient Khmer Empire"*, has been written by L. P. Briggs. The data are derived from Chinese dynastic histories and Oriental travellers' accounts ; Sanskrit and Khmer epigraphy ; Buddhic and Brahmanic iconography; architecture, art and sculpture; bas-reliefs; and excavations.

Three periods are distinguished : the Funan (first to sixth centuries); the Chenla (sixth century to 802); and the Kambuja or Angkor (802-1431). The Funan period is that of a small kingdom on the Melkong delta, inhabited by a people who may have had negrito racial elements and have spoken a preKhmer Austro-Asiatic language. They are believed to have been conquered in the first century by a foreign invader (possibly Malay) who married their queen and introduced clothing among their women. Direct relations with India and China date from the third century. An Indian Brahman is recorded to have become king of Funan in the fifth century, and to have introduced, among other customs, state

* "The Ancient Khmer Empire." Pp. 295, with 17 maps and 58 figures. (Trans. American Phil. Soc., 41, Part 1; 1951.) worship of the Siva-linga and a Central Indian alphabet.

Funan was conquered and became a vassal king. dom of Chenla to the north in 550, the Chenlas being a Mon-Khmer people who had obtained their own kingdom by an earlier conquest of the Chams. The Chenla people were already acquainted with the Siva cult and with the Sanskrit Puranas and Fpics. The united kingdom of Chenla and Funan was tem. porarily conquered by the Malays some time in the eighth century.

The Kambuja period opens with a line of kings who considered themselves incarnations of Siva and who founded a Devaraja cult, each new king being appointed by the head of a family of Brahman purohitas, among whom, unlike the rest of the population, descent was matrilineal. This was the classical period of Cambodian history, marked by a great expansion of the empire, a magnificent flowering of architecture and art, and a unique syncretism of Saivism, Vishnuism and Mahayana Buddhism. With the increasing influence of Buddhism, the Devaraja cult gave place to the cult of a Buddharaja. There was a decline in art and architecture in the thirteenth century, probably coincident with the introduction of Hinayana Buddhism. The period ends with the Siamese sacking of Angkor in 1431, and the removal of the capital to the south-east part of the kingdom. Though the Khmers gave to the world no system of administration or ethics, no literature and no philosophy, their civilization saw the summit of Oriental architecture and decoration.

\section{KATHLEEN GOUGH}

\section{FOREST RESEARCH IN SWEDEN}

$V^{\infty}$ OL. 39 of the memoirs of the Forest Research Institute of Sweden* contains a number of articles of varied interest. Erik Holmsgard discusses height increment, development of the crown, self-pruning, etc., in young beech stands. His investigations seem to show great variations in height increment in various years, and this does not necessarily depend upon changes in climate; thus, the highest trees in a young stand will not necessarily remain so. The growth in height of the lateral branches and the height increment of the lower trees are more influenced by the light conditions than by the climate. It is impossible to give here the author's detailed conclusions, for which the paper should be consulted.

Henrik Petterson deals with the application of the new forestry conservation law passed in 1948, which aims in general at economic forest utilization with a constant yield. Mr. Petterson admits that it may seem futile under present conditions, when the outlook is so uncertain, to attempt to direct the utilization of forests toward an economic goal. The law differentiates between well-grown forests and those which are badly grown or tended : the former, apart from thinnings, may not be clear-felled without the consent of the Forest Conservation Bureau; and the latter must not be treated in such a manner as to result in further deterioration. Further, such measures must be carried out as will result in an improve. ment of the stocking of the forest within a reasonable time. The paper discusses the methods by which the law can be carried out. There is no indication

* Meddelanden fran Statens Skogs-Forskningsinstitut, Band 39 1950-51 (Stockholm, 1951). 
that it proposes anything quite so drastic as the dedication scheme envisaged by the Forestry Commission in Great Britain.

A third paper of interest, by Marianne Lekander, treats of the invasions of insect pests in the Swedish forests during 1741-1945. The author has studied the whole of the literature - the forestry and entomological, administration and departmental reports of the State and reports of forestry conservators and the institute of research-and the paper appears to be an admirable piece of work. Mass invasions or slighter ones occurring more often are classified for each species of insect in a chronological order and are given for each of the forest conservancies in each province. A tabular statement is given at the end of the paper enumerating the chief pests of the forests during a period of fifty years, 1896-1945. An alphabetical list of the insects mentioned is given in Latin and Swedish.

Another paper, by Lars Tiren, is "On Clearing Spruce and its Significance for the Reforestation of Spruce Forest Clearings in Northern Sweden". The main objective was to study the nature and abundance of the seed and resulting seedling growth occurring from the spruce trees left standing in the forests in northern Sweden, and a good opportunity occurred in the good spruce seeding year 1942-43. In these northern spruce forests the future crop largely depends upon the poor type of tree called 'clearing spruce' or 'remnant spruce'. Even though these trees often appear very insignificant and inefficient for the purpose required, they do in effect function as seed-bearers, though often assisted by contribu. tions from any forest border trees surrounding them. Briefly, the study has shown that some artificial help can assist, which may consist of raking under the trees or burning under them, providing a sufficiency of good trees remains to assist the others. Much further research requires to be carried out, which should prove of value to other parts of the world where forests growing under the same type of conditions exist.

\section{CHEMICALS IN FOOD}

$\mathrm{T}$

HE United States Congress established in June 1950 a Select Committee, known as the Delaney Committee, which was given the task of assessing the dangers to public health arising from the increasing use of chemical substances in food manufacture and from the presence in foods of residues from the pesticides now widely employed in agriculture. This Committee has issued its preliminary findings* together with a full report $\dagger$ which is an important document embodying in its eight hundred pages the views of some seventy scientific workers, physicians and industrialists who appeared as witnesses.

The Committee heard the striking evidence submitted by the officers of the Food and Drug Administration, who stated that 704 extraneous substances were thought to be in use ; of these, only 428 were considered harmless as normally employed, leaving a further 276 of which the safety was open to question. Attention was directed to a conflict of opinions

* Investigation of the Use of Chemicals in Food Products. 1951 Union Calendar No. 1139. Report No. 3254. (U.S. Gov. Printer, Washington, D.C.)

t Chemicals in Food Products. Hearings before the House Select Committee. 1951. (U.S. Gov, Printer, Washington, D.C.) regarding the suitability of various compounds. There are several which were at one time considered harmless and which found a place among food ingredients; later investigations established their toxic character. In this category are $p$-phenetyl urea, used for more than fifty years as a sugar substitute; chloracetic acid, a preservative for wines; and thiourea, an anti-browning agent for fruits. The dyestuff butter yellow served for many years as a food colour before its carcinogenic action was recog. nized, and lithium chloride was considered safe until it was shown to be fatal to persons living on a low salt (sodium chloride) diet.

'The above substances are no longer employed, but there are others in use which are the subject. of controversy; and although those materials which act as preservatives, anti-oxidants and mould inhibitors are added to food in very small quantities, others such as the synthetic emulsifiers used in the United States baking industry may be present in considerable amounts. Many witnesses pointed to the dangers that could result from the incorporation of these newrr ingredients in a staple commodity such as bread.

Consideration was given not only to those substances which are added deliberately to foods to produce some desired effect, but also to others which may become associated with foodstuffs by accident. Among these are the surface-active agents employed in the cleaning of food utensils and machinery, and the pesticides, such as DDT, which may adhere to crops and find their way into foodstuffs. The very properties which make these substances so effective in the control of lower forms of life may lead to their absorption by plant tissues and to their injurious effects on higher animals.

Testimony was given regarding the difficulties experienced in devising suitable methods for the accurate estimation of many of the newer synthetic substances, especially at the low levels at which they are likely to occur in foods. Sound practical analytical methods are essential if there is to be adequate control of the degree of contamination of foods and if the pharmacological properties of the compounds are to be investigated.

Many scientific workers stressed the necessity of carefully designed toxicity studies. They pointed out that, in the past, the main emphasis had perhaps been on acute toxicity tests to discover the levels at which a substance would produce deaths in experimental animals within a short period of time after it had been given by mouth or by injection. In the light of experience gained over the past decade more detailed investigations are required-feeding experiments at different levels on several species of animals over a period of perhaps two years, together with a thorough study of the metabolism of the substance under discussion, its effects on the tissues of the experimental animals and its relation to growth, reproduction and lactation. The results of some of these chronic toxicity studies were quoted; there were substances which appeared to be harmless in short-term experiments-in that they did not cause death immediately following ingestion-yet small amounts accumulated in the body and ultimately produced permanent injury.

Experiments on the chlorinated hydrocarbon DDT were described which demonstrated that DDT appeared in the flesh of chickens, cows and sheep which had eaten crops sprayed with the pesticide. It was present also in eggs and in milk. Moreover, 